\title{
Valuing all knowledges through an expanded definition of access
}

COMMENTARY ON RACE AND ETHNICITY IN FOOD SYSTEMS

\author{
Kareem M. Usher* \\ The Ohio State University
}

Submitted June 15, 2015 / Published online August 24, 2015

Citation: Usher, K. M. (2015). Valuing all knowledges through an expanded definition

of access. Journal of Agriculture, Food Systems, and Community Development, 5(4), 109-114.

http://dx.doi.org/10.5304/jafscd.2015.054.018

Copyright (C) 2015 by New Leaf Associates, Inc.

\begin{abstract}
Historical racial injustices as well as more recent public and economic policies have culminated in the displacement of supermarkets from some central city neighborhoods. With this displacement, many low-income and minority neighborhoods not only have been deprived of affordable healthful food, but also have experienced prolonged exposure to energy-dense and highly processed snack foods. Partly as a consequence of this loss of supermarkets, diet-related diseases have become prevalent. Our current policies to improve this health issue address only objective measures of access, with little input from community residents, and they are having limited results. In response, I have reconceptualized access as a construct with

\footnotetext{
* Kareem M. Usher, PhD, Assistant Professor, City and Regional Planning, The Ohio State University; Austin E. Knowlton School of Architecture-City and Regional Planning Section; 275 West Woodruff Avenue; Columbus, Ohio 43210 USA; usher.21@,osu.edu
}

five dimensions: acceptability, accessibility, accommodation, affordability, and availability. This new expanded view supports both objective and perceived aspects of access and values the knowledge of residents through community-based participatory research, thereby providing a more complete understanding of access.

\section{Keywords}

food access, race, five dimensions of access, grocery gap, health disparity, community-based participatory research, social determinants of health, food desert

$\Upsilon \begin{aligned} & \text { he increase in youth obesity rates and diet- } \\ & \text { related diseases across age groups in low- }\end{aligned}$ income and predominantly minority neighborhoods relative to middle-class White neighborhoods has received national attention of late (Bodor, Rice, Farley, Swalm, \& Rose, 2010; Zenk, Schulz, Israel, James, Bao, \& Wilson, 2005). Our attempts at reducing this disparity and improving 
health outcomes by increasing access to healthy foods have had limited and uneven success (Guthman, 2008a, 2008b; Slocum, 2007). In this commentary, I suggest that we reconceptualize and broaden our definition of "access" to go beyond objective measures of location, affordability, and availability to include emotive components such as acceptability, accommodation, and residents' perceptions of their food environment and foodways (Usher, 2015). This expanded notion of access supports community-based participatory research that values the knowledge of and includes residents as research partners, and provides for a more complete understanding of food insecurity, food sovereignty, and deprived areas or "food deserts."

Many studies, although not all, have suggested that having access to full-service supermarkets influences families' selection and consumption of fresh fruits and vegetables, and thus affect their long-term health outcomes (Grigsby-Toussaint, Zenk, Odoms-Young, Ruggiero, \& Moise, 2010; Pothukuchi, 2005; Raja, Yin, Roemmich, Ma, Epstein, Yadav, \& Ticoalu, 2010). This is based on research that has found that supermarkets are the best sources of a variety of high-quality, healthful food at affordable prices throughout the year (Caspi, Kawachi, Subramanian, Adamkiewicz, \& Sorensen, 2012; Laraia, Siega-Riz, Kaufman, \& Jones, 2004). Not only do low-income minority neighborhoods suffer by having fewer supermarkets than upper-class White neighborhoods, but also there is a statistically significant link between the racial composition of a neighborhood and the density of fast-food restaurants (Block, Scribner, \& DeSalvo, 2004). Kwate's (2008) work in New York City showed that the dominant factor in determining fast-food density in majority Black neighborhoods is race-based residential segregation. Block and colleagues (2004) found that predominantly Black (80 percent or higher) neighborhoods were geographically associated with fast-food restaurants even after controlling for commercial activity, the presence of highways, and median home values. They also found that there were 2.4 fast food restaurants per square mile in majority Black neighborhoods compared to 1.5 restaurants per square mile in majority White neighborhoods. Race is also a significant factor in the presence of large chain supermarkets. Black neighborhoods tend to have half the availability of supermarkets of White neighborhoods, and lowincome African Americans on average live 1.1 miles (1.8 kilometers) further from the nearest supermarket than low-income White families (Block et al., 2004; Odoms-Young, Zenk, \& Mason, 2009; Powell, Slater, Mirtcheva, Bao, \& Chaloupka, 2007).

As our selection and consumption of food are largely based on the choices we have in our neighborhood of residence, it follows that low-income minority residential areas that tend to have fewer health-promoting resources such as supermarkets that offer high-fiber foods, and have prolonged exposure to highly processed, energy-dense foods, also display higher rates of cardiovascular diseases (Diez Roux, 2001; Ver Ploeg, 2010; Walker, Block, \& Kawachi, 2012). In addition, a 2012 U.S. Department of Agriculture study found that 16.4 percent of the population, or 50.1 million people, lived in food-insecure neighborhoods, and 37.6 percent of these were low-income residents (Coleman-Jensen, Nord, Andrews, \& Carlson, 2012). African Americans, Hispanics, and other minority groups have higher rates of morbidity and mortality rates, and suffer disproportionately from "diseases of lifestyle" namely coronary heart disease and Type II Diabetes, than Whites (Eisenhauer, 2001; Short, Guthman, \& Raskin, 2007). Obesity, for example, is 50 percent more prevalent in low-income households, which tend to be in areas that lack other amenities such as parks and full-service supermarkets (Laska, Hearst, Forsyth, Pasch, \& Lytle, 2010; Morland, Diez Roux, \& Wing, 2006).

In addressing this disparity in health outcomes, some municipalities have recognized that they are less the result of genetics, individual behavior, or access to health care, and more a consequence of historical, social, physical, and economic factors that shape opportunities for neighborhoods-or social determinants of health. These observed realities are often predicated on systemic inequities that marginalize groups based on racial and ethnic identity, religion, gender, age, socioeconomic status, mental health, sexual orientation, and geographic location (Food in Neighborhoods Committee, 2010; L. M. Smith, 2008; P. Smith, 
Pennington, Crabtree, \& Illback, 2011). However, our extant notion of access does not reflect this insight. Current policies attempt to fill the "grocery gap" and to make healthful food more affordable through subsidies (Bell, Mora, Hagan, Rubin, \& Karpyn, 2013; Bitler \& Haider, 2011; Song, Gittelsohn, Kim, Suratkar, Sharma, \& Anliker, 2009). While these are useful and necessary, they are not sufficient. More scholars are calling for studies and policies that consider perceived as well as objective access and value self-reporting as reasonable measures of access (Alkon, Block, Moore, Gillis, DiNuccio, \& Chavez, 2013; DeLind, 2006; Moore, Diez Roux, \& Franco, 2012). For example, at present access does not consider residents' perception of food quality or neighborhood crime rates. Winkler, Turrell, and Patterson (2006) found no differences in price and availability of healthy food based on the socioeconomic characteristics of their study area. And Coveney and O'Dwyer (2009) concluded that living in a "food desert," by itself, did not hinder access to healthy food. Residents were able to mitigate this obstacle through social networks that provided access through private transportation to food outside their neighborhoods.

Access incorporates objective as well as

\section{Figure 1. The Five Dimensions of Access}

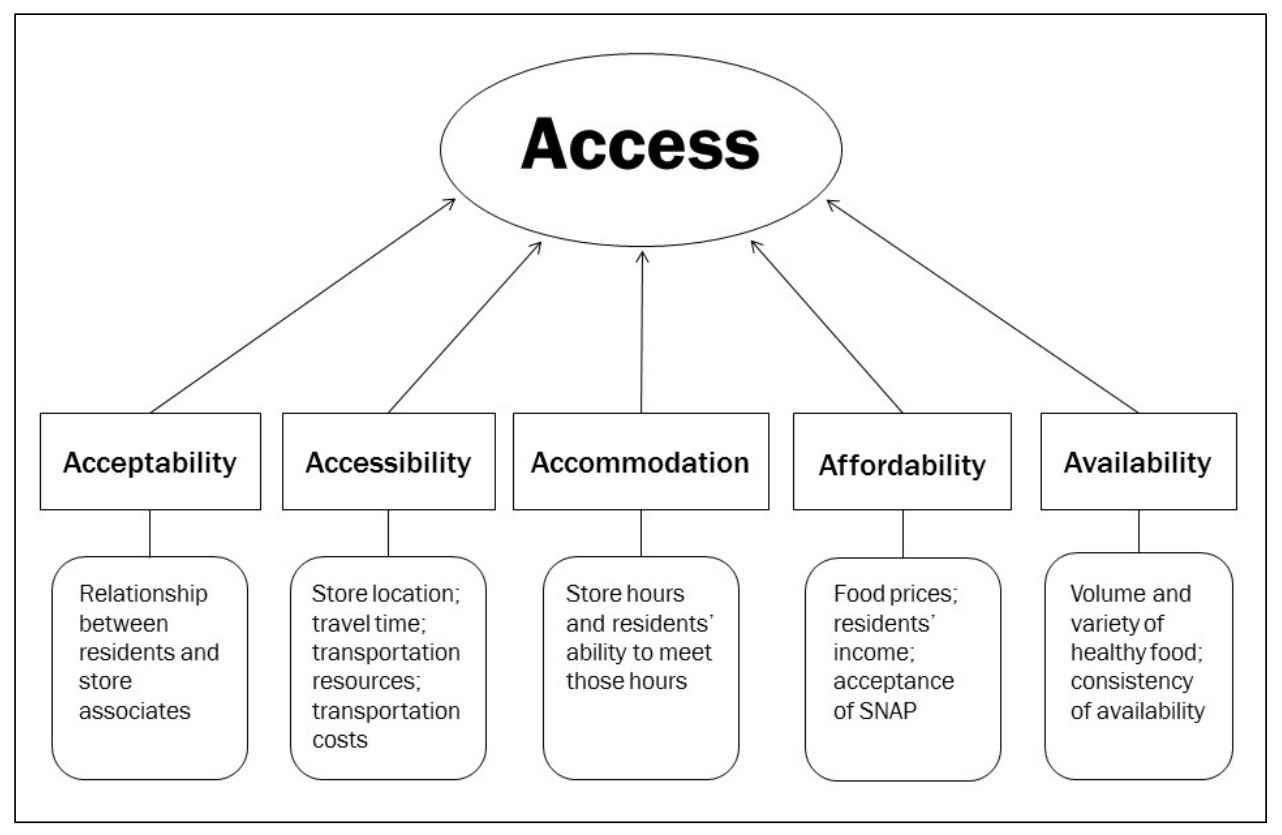

perceived elements, and it is a dynamic, not static, condition; that is, it is not realistic to expect that attracting a new supermarket will solve all food access issues in perpetuity. Given these constraints, I have reconceptualized "access" to reflect a construct that is an aggregation of factors (or "strands") that influences residents' ability to acquire and benefit from healthy food (Penchansky \& Thomas, 1981; Ribot \& Peluso, 2003). This conceptualization highlights the social interactions, cultural norms, socio-political, and economic factors that influence access to resources across the landscape. As these factors interact with each other and residents orient themselves geographically in relation to resources over time, the strands affect residents' power or self-efficacy and level of access to resources (Penchansky \& Thomas, 1981; Ribot $\&$ Peluso, 2003; Usher, 2015). In this way access is understood as the level of "fit" between residents and the local food system and residents' ability to meet their nutritional needs.

I illustrate this conceptualization of the Five Dimensions of Access in Figure 1. The five dimensions are Acceptability, Accessibility, Accommodation, Affordability, and Availability. Acceptability is defined as the relationship between customers and store associates, including owners. It considers residents' attitudes toward the quality and cultural appropriateness of the food being sold. Accessibility queries residents' perceptions of the relationship between the location of the food sources and the location of residents, taking account of residents' transportation resources, travel time, distance, and transportation costs.

The third dimension is Accommodation, which I define as the 
residents' perceptions of the manner in which healthy food is organized to meet residents' needs. This refers to residents' perception of store hours of operation, food displays, the physical condition of the venue, and perception of area crime. Affordability refers to residents' perception of their ability to purchase the food, including consideration of their income and their knowledge of food prices outside their neighborhoods for comparison shopping. This dimension also includes the food sources' ability to make healthy food more attractive to residents through subsidies and discounts. Finally, the fifth dimension is Availability, which investigates the relationship between the volume and variety of healthy food and the needs of residents, as well as the availability of food throughout the year (Usher, 2015).

Each of these five dimensions is dynamic and not easily separated. For instance, a family might move to another neighborhood, affecting their accessibility to healthy food, or a family member might secure a better-paying job, which may affect perceptions of affordability and accessibility. However, the model remains stable. It is also important that this model creates both the intellectual and scientific space for us to conduct community-based participatory research (CBPR) and for us to value self-reporting as a valid source of knowledge by incorporating both objective and perceived measures of food access. In this way we-social scientists, policy analysts, and community stakeholders-involve local residents as true partners (Arnstein, 1969), empower residents in problemsolving, build social capital, and gain a more complete view of families' food environments and an understanding of food choices in order to develop more effective local food policies to improve the health of all.

\section{References}

Alkon, A. H., Block, D., Moore, K., Gillis, C., DiNuccio, N., \& Chavez, N. (2013). Foodways of the urban poor. Geoforum, 48, 126-135. http://dx.doi.org/10.1016/i.geoforum.2013.04.021

Arnstein, S. R. (1969). A ladder of citizen participation. Journal of the American Institute of Planners, 35(4), 216224.

http://dx.doi.org/10.1080/01944366908977225
Bell, J., Mora, G., Hagan, E., Rubin, V., \& Karpyn, A. (2013). Access to bealthy food and why it matters: A review of the research. Oakland, California: PolicyLink and Philadelphia, Pennsylvania: The Food Trust. Retrieved from the PolicyLink website: https://www.policylink.org/sites/default/files/ GROCERYGAP_FINAL_NOV2013.pdf

Bitler, M., \& Haider, S. J. (2011). An economic view of food deserts in the United States. Journal of Policy Analysis and Management, 30(1), 153-176. http://dx.doi.org/10.1002/pam.20550

Block, J. P., Scribner, R. A., \& DeSalvo, K. B. (2004). Fast food, race/ethnicity, and income: A geographic analysis. American Journal of Preventive Medicine, 27(3), 211-217. http://dx.doi.org/10.1016/j.amepre.2004.06.007

Bodor, J. N., Rice, J. C., Farley, T. A., Swalm, C. M., \& Rose, D. (2010). Disparities in food access: Does aggregate availability of key foods from other stores offset the relative lack of supermarkets in AfricanAmerican neighborhoods? Preventive Medicine, 51(1), 63-67.

http://dx.doi.org/10.1016/j.ypmed.2010.04.009

Caspi, C. E., Kawachi, I., Subramanian, S. V., Adamkiewicz, G., \& Sorensen, G. (2012). The relationship between diet and perceived and objective access to supermarkets among lowincome housing residents. Social Science \& Medicine, 75(7), 1254-1262.

http://dx.doi.org/10.1016/j.socscimed.2012.05.014

Food in Neighborhoods Committee. (2010). The state of food: A snapshot of food access in Lonisville. Louisville, Kentucky: Mayor's Healthy Hometown Movement. Retrieved from the Congressional Hunger Center website: http://www.hungercenter.org/publica tions/the-state-of-food-a-snapshot-of-food-accessin-louisville/

Coleman-Jensen, Alisha, Mark Nord, Margaret Andrews, and Steven Carlson. 2012. "Household Food Security in the United States in 2011: Statistical Supplement."

Coveney, J., \& O'Dwyer, L. A. (2009). Effects of mobility and location on food access. Health \& Place, 15(1), 45-55. http://dx.doi.org/10.1016/ j.healthplace.2008.01.010

DeLind, L. B. (2006). Of bodies, place, and culture: Resituating local food. Journal of Agricultural and Environmental Ethics, 19(2), 121-146. http://dx.doi.org/10.1007/s10806-005-1803-z 
Diez Roux, A. V. (2001). Investigating neighborhood and area effects on health. American Journal of Public Health, 91(11), 1783-1789. Retrieved from http://www.pubmedcentral.nih.gov/articlerender. fcgi?artid $=1446876$

Eisenhauer, E. (2001). In poor health: Supermarket redlining and urban nutrition. GeoJournal, 53(2), 125-133. http://dx.doi.org/10.1023/A:1015772503007

Grigsby-Toussaint, D. S., Zenk, S. N., Odoms-Young, A., Ruggiero, L., \& Moise, I. (2010). Availability of commonly consumed and culturally specific fruits and vegetables in African-American and Latino neighborhoods. Journal of the American Dietetic Association, 110(5), 746-752. http://dx.doi.org/10.1016/j.jada.2010.02.008

Guthman, J. (2008a). Bringing good food to others: Investigating the subjects of alternative food practice. Cultural Geographies, 15(4), 431-447. http://dx.doi.org/10.1177/1474474008094315

Guthman, J. (2008b). "If they only knew": Color blindness and universalism in California alternative food institutions. The Professional Geographer, 60(3), 387-397. http://dx.doi.org/10.1080/00330120802013679

Kwate, N. O. A. (2008). Fried chicken and fresh apples: Racial segregation as a fundamental cause of fast food density in black neighborhoods. Health \& Place, 14(1), 32-44. http://dx.doi.org/10.1016/ j.healthplace.2007.04.001

Laraia, B. A., Siega-Riz, A. M., Kaufman, J. S., \& Jones, S. J. (2004). Proximity of supermarkets is positively associated with diet quality index for pregnancy. Preventive Medicine, 39(5), 869-875. http://dx.doi.org/10.1016/i.ypmed.2004.03.018

Laska, M. N., Hearst, M. O., Forsyth, A., Pasch, K. E., \& Lytle, L. (2010). Neighbourhood food environments: Are they associated with adolescent dietary intake, food purchases and weight status? Public Health Nutrition, 13(11), 1757-1763. http://dx.doi.org/10.1017/S1368980010001564

Moore, L. V., Diez Roux, A. V., \& Franco, M. (2012). Measuring availability of healthy foods: Agreement between directly measured and self-reported data. American Journal of Epidemiology, 175(10), 1037-1044. http://dx.doi.org/10.1093/aje/kwr445

Morland, K. B., Diez Roux, A. V., \& Wing, S. (2006). Supermarkets, other food stores, and obesity: The Atherosclerosis Risk in Communities Study.
American Journal of Preventive Medicine, 30(4), 333-339. http://dx.doi.org/10.1016/j.amepre.2005.11.003

Odoms-Young, A. M., Zenk, S., \& Mason, M. (2009). Measuring food availability and access in AfricanAmerican communities: Implications for intervention and policy. American Journal of Preventive Medicine, 36(4 Suppl.), S145-S150. http://dx.doi.org/10.1016/j.amepre.2009.01.001

Penchansky, R., \& Thomas, J. W. (1981). The concept of access: Definition and relationship to consumer satisfaction. Medical Care, 19(2), 127-140. http://dx.doi.org/10.1097/00005650-198102000$\underline{00001}$

Pothukuchi, K. (2005). Attracting supermarkets to inner-city neighborhoods: Economic development outside the box. Economic Development Quarterly, 19(3), 232-244. http://dx.doi.org/10.1177/0891242404273517

Powell, L. M., Slater, S., Mirtcheva, D., Bao, Y., \& Chaloupka, F. J. (2007). Food store availability and neighborhood characteristics in the United States. Preventive Medicine, 44(3), 189-195. http://dx.doi.org/10.1016/j.ypmed.2006.08.008

Raja, S., Yin, L., Roemmich, J., Ma, C., Epstein, L., Yadav, P., \& Ticoalu, A. B. (2010). Food environment, built environment, and women's BMI: Evidence from Erie County, New York. Journal of Planning Education and Research, 29(4), 444-460. http://dx.doi.org/10.1177/0739456X10367804

Ribot, J. C., \& Peluso, N. L. (2003). A theory of access. Rural Sociology, 68(2), 153-181. http://dx.doi.org/ 10.1111/j.1549-0831.2003.tb00133.x

Short, A., Guthman, J., \& Raskin, S. (2007). Food deserts, oases, or mirages? Small markets and community food security in the San Francisco Bay Area. Journal of Planning Education and Research, 26(3), 352-364. http://dx.doi.org/10.1177/0739456X06297795

Slocum, R. (2007). Whiteness, space and alternative food practice. Geoforum, 38(3), 520-533. http://dx.doi.org/10.1016/j.geoforum.2006.10.006

Smith, L. M. (Director). (2008). In sickness and in wealth [Television series episode transcript]. In L. Adelman (Exective Producer), Unnatural causes: Is inequality making us sick? San Francisco: California Newsreel and Boston: Vital Pictures. 
Smith, P., Pennington, M., Crabtree, L., \& Illback, R. (2011). Louisville Metro Health Equity Report: The social determinants of health in Louisville Metro neighborhoods. Louisville, Kentucky: Louisville Metro Department of Public Health and Wellness Center for Health Equity.

Song, H.-J., Gittelsohn, J., Kim, M., Suratkar, S., Sharma, S., \& Anliker, J. (2009). A corner store intervention in a low-income urban community is associated with increased availability and sales of some healthy foods. Public Health Nutrition, 12(11), 2060-2067. http://dx.doi.org/10.1017/S1368980009005242

Usher, K. M. (2015). Access to bealthy food re-conceptualized: Exploring the five dimensions of access. Manuscript in preparation.

Ver Ploeg, M. (2010, March 1). Access to affordable, nutritious food is limited in "food deserts." Amber $W$ aves. Retrieved from http://www.ers.usda.gov/ amber-waves /2010-march/access-to-affordable,nutritious-food-is-limited-in- $\% \mathrm{E} 2 \% 80 \%$ Cfooddeserts $\% \mathrm{E} 2 \% 80 \% 9$ D.aspx \#.Vds6HZehNnA
Walker, R. E., Block, J., \& Kawachi, I. (2012). Do residents of food deserts express different food buying preferences compared to residents of food oases? A mixed-methods analysis. International Journal of Behavioral Nutrition and Physical Activity, 9, 41. http://dx.doi.org/10.1186/1479-5868-9-41

Winkler, E., Turrell, G., \& Patterson, C. (2006). Does living in a disadvantaged area entail limited opportunities to purchase fresh fruit and vegetables in terms of price, availability, and variety? Findings from the Brisbane Food Study. Health \& Place, 12(4), 741-748. http://dx.doi.org/10.1016/ j.healthplace.2005.09.006

Zenk, S. N., Schulz, A. J., Israel, B. A., James, S. A., Bao, S., \& Wilson, M. L. (2005). Neighborhood racial composition, neighborhood poverty, and the spatial accessibility of supermarkets in metropolitan Detroit. American Journal of Public Health, 95(4), 660667. http://dx.doi.org/10.2105/AJPH.2004.042150 